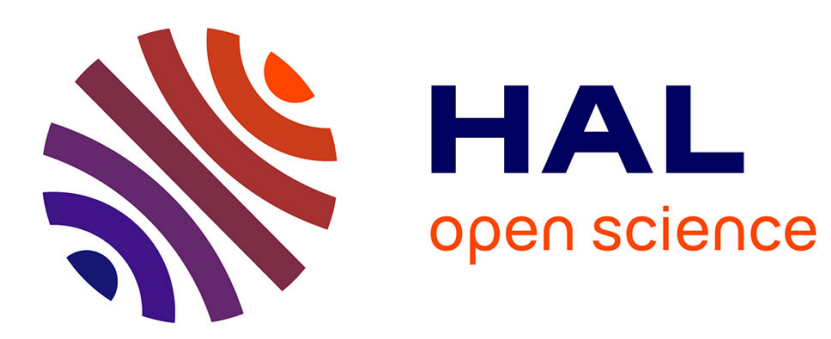

\title{
The working group for "basic science" in ITP at the International Cooperative ITP Study Group (ICIS)
}

Kenneth J. Clemetson, Simon Panzer

\section{To cite this version:}

Kenneth J. Clemetson, Simon Panzer. The working group for "basic science" in ITP at the International Cooperative ITP Study Group (ICIS). Annals of Hematology, 2010, 89 (s1), pp.3-4. 10.1007/s00277-009-0883-7 . hal-00535114

\section{HAL Id: hal-00535114 \\ https://hal.science/hal-00535114}

Submitted on 11 Nov 2010

HAL is a multi-disciplinary open access archive for the deposit and dissemination of scientific research documents, whether they are published or not. The documents may come from teaching and research institutions in France or abroad, or from public or private research centers.
L'archive ouverte pluridisciplinaire $\mathbf{H A L}$, est destinée au dépôt et à la diffusion de documents scientifiques de niveau recherche, publiés ou non, émanant des établissements d'enseignement et de recherche français ou étrangers, des laboratoires publics ou privés. 


\title{
The working group for "basic science" in ITP at the International Cooperative ITP Study Group (ICIS)
}

\author{
Kenneth J. Clemetson • Simon Panzer
}

Received: 28 October 2009 /Accepted: 2 December 2009/Published online: 22 April 2010

(C) Springer-Verlag 2010

\begin{abstract}
A variety of studies were considered necessary to better understand the etiology of idiopathic thrombocytopenic purpura. Apoptosis of platelets and megakaryocytes were strong proposals, calling for collaboration. Some groups want to study microparticles and thombin generation in order to understand the variation of the bleeding tendency in patients. Viral antigen cross-reaction with platelet epitopes was another topic that was addressed. Kinetics of cytokines may further contribute to our understanding of the disease.
\end{abstract}

Keywords Autoimmune thrombocytopenia - Basic science . Collaboration

\section{Introduction}

The group discussed the origins of idiopathic thrombocytopenic purpura (ITP) and the feeling that it has a variety of

The working group for "basic science" in ITP at the International Cooperative ITP Study Group (ICIS) was chaired by Kenneth Clemetson from Bern and Simon Panzer from Vienna. The group comprised about 20 attendees.

\section{K. J. Clemetson}

Theodor Kocher Institute, University of Berne,

Berne, Switzerland

\section{S. Panzer $(\bowtie)$}

Clinical Department for Blood Group Serology and Transfusion

Medicine, Division of Blood Group Serology,

Medical University of Vienna,

Waehringer Guertel 18-20,

1090 Vienna, Austria

e-mail: simon.panzer@meduniwien.ac.at etiologies, even if acute onset and chronic (in adulthood) are already considered separately. Further, this variety may persist after excluding "secondary" ITP in diseases like lupus erythematosus. The following suggestions for further directions of research may assist to characterize better the pathoetiology of the disease.

As acute ITP is thought to be associated with viral infections, characterization of cross-reacting viral and platelets epitopes was suggested [1,2]. This could be accomplished by work on the 3-D structures of the epitopes on the one hand, and by the production of the relevant peptides and antibody binding studies on the other hand. However, none of the participants has the necessary expertise to carry on such investigations.

It is clear that the platelet count is only a surrogate marker for the risk of bleeding. However, some individuals hardly have bleedings at very low platelet counts of $<20 \times$ $10^{9} / 1$ while others may bleed at a platelet count of $<50 \times$ $10^{9} / 1$. Therefore, a very good characterization of platelets, megakaryocytes, and plasma factors for coagulation active mechanisms was felt necessary.

(a) In particular, platelet and megakaryocyte apoptosis was suggested to be of importance [3, 4]. The group around Oliver Speer and Markus Schmugge (University Children's Hospital, Zürich, Switzerland) is interested in such studies and called for collaboration with other groups to provide carefully defined sera or plasma from patients as well as providing bone marrow material. Material obtained at various periods throughout the disease would be advantageous for such studies. A study proposal is shown at the end of this report.

(b) A possible compensation of the coagulation system for the low platelet count that is met in some individuals, but not in others, may contribute to less bleeding. Therefore, 
microparticles and thrombin generation may serve to overcome the low platelet counts [5]. Some groups have started to look into these mechanisms.

Another topic is cytokine regulation on serially obtained samples. John Semple (Toronto, Canada) would be interested in such studies. Such studies may advance our knowledge on $\mathrm{T}$ cell/B cell interaction during the course of the disease. Currently, the main body of data has been published on single observation snapshots [6-8].

Familiar onset of ITP and genetic predisposition is a very interesting subject [9, 10]. Johannes Rischewski, Basel, is collecting these samples and studies family genetics. Again, collaboration with others would improve the power of these investigations.

Conflict of interest The authors have no conflict of interest to declare.

\section{References}

1. Cines DB, Blanchette VS (2002) Immune thrombocytopenic purpura. N Engl J Med 346:995-1008

2. Provan D, Stasi R, Newland AC, Blanchette VS, Bolton-Maggs P, Bussel JB, Chong BH, Cines DB, Gernsheimer TB, Godeau B, Grainger J, Greer I, Hunt BJ, Imbach PA, Lyons G, McMillan R, Rodeghiero F, Sanz MA, Tarantino M, Watson S, Young J, Kuter DJ (2009) International consensus report on the investigation and management of primary immune thrombocytopenia. Blood. doi:10.1182/blood-2009-06-225565

3. Mason KD, Carpinelli MR, Fletcher JI, Collinge JE, Hilton AA, Ellis S, Kelly PN, Ekert PG, Metcalf D, Roberts AW, Huang DC, Kile BT (2007) Programmed anuclear cell death delimits platelet life span. Cell 128:1173-1186

4. Kile BT (2009) The role of the intrinsic apoptosis pathway in platelet life and death. J Thromb Haemost Suppl 1:214-217

5. Smyth SS, McEver RP, Weyrich AS, Morrell CN, Hoffman MR, Arepally GM, French PA, Dauerman HL, Becker RC; for the 2009 platelet colloquium participants (2009). Platelet functions beyond haemostasis. J Thromb Haemost doi:10.1111/j.1538-7836.2009.03586

6. Semple JW, Milev Y, Cosgrave D, Mody M, Hornstein A, Blanchette V, Freedman J (1996) Differences in serum cytokine levels in acute and chronic autoimmune thrombocytopenic purpura: relationship to platelet phenotype and antiplatelet T-cell reactivity. Blood 87:4245-4254

7. Olsson B, Andersson PO, Jernås M, Jacobsson S, Carlsson B, Carlsson LM, Wadenvik H (2003) T-cell-mediated cytotoxicity toward platelets in chronic idiopathic thrombocytopenic purpura. Nat Med 9:1123-1124

8. Zhou Z, Chen Z, Li H, Chen X, Xu J, Gu D, Du W, Zheng C, Zhang L, Huang Y, Ren Q, Yang R (2009) BAFF and BAFF-R of peripheral blood and spleen mononuclear cells in idiopathic thrombocytopenic purpura. Autoimmunity 42:112-119

9. Gaiger A, Neumeister A, Heinzl H, Pabinger I, Panzer S (1994) HLA class-I and -II antigens in chronic idiopathic autoimmune thrombocytopenia. Ann Hematol 68:299-302

10. Thomaz Maia MH, de Lima Peixoto R, Silva de Lima CP, Magalhães M, Sena L, do Socorro Silva Costa P, Brasil Barbosa F, de Oliveira LF, Romero M, Nogueira de Araujo Silva C, Melo Dos Santos EJ (2009). Predisposition to idiopathic thrombocytopenic purpura maps close to the MICA gene. Hum Immunol. doi:10.1016/j.humimm.2009.01.011 